\title{
Helse som utenrikspolitikk 违
}

\author{
Den globale helsearenaen kan synes å være dominert av bistandsorganisasjoner, filantroper som Bill Gates \\ og farmasøytisk industri. Hvilken rolle kan helse- og utenriksministeriene spille?
}

Engelsk oversettelse av hele artikkelen på www.tidsskriftet.no

\section{Kristin Ingstad Sandberg \\ k.i.sandberg@medisin.uio.no \\ Institutt for samfunn og helse/ \\ Senter for utvikling og miljø \\ Universitetet i Oslo}

Steinar Andresen

Fridtjof Nansens Institutt

Sissel Hodne Steen

Utenriksdepartementet

Sigrun Møgedal

Nasjonalt kunnskapssenter for helsetjenesten

Kristine Husøy Onarheim

Institutt for samfunnsmedisinske fag

Universitetet i Bergen

Graziella Van den Bergh

Avdeling for helse- og sosialfag

Høgskolen i Bergen

En sensommerdag i 1851 satt delegater fra 12 land samlet rundt bordet $\mathrm{i}$ det franske utenriksministeriet. De var kommet sammen for å finne en løsning som kunne hindre spredning av sykdom over landegrensene. Kolera, pest og gulfeber var problemet. Hvert land hadde to personer ved forhandlingsbordet, én lege og én diplomat (1). Denne første «International Sanitary Conference» er en av de tidligste eksemplene på forsøk på å skape internasjonale avtaler. Slik var helse et pionerområde for globalt samarbeid.

Verden er fremdeles slik at en rekke sykdomsutfordringer ikke kan løses innenfor de enkelte lands grenser, men avhenger av samarbeid i regionale og internasjonale fora. Samarbeidet har tatt mange former, men det tok mer enn et århundre fra den første bindende internasjonale helseavtalen kom i havn i 1892 - om bl.a. karanteneregler for skipsfart mellom verdensdelene til den neste - Den internasjonale tobakkskonvensjonen - i 2003. Det siste tiåret er aktiviteten blitt en helt annen: Begrepet helsediplomati brukes om de stadig hyppigere forhandlinger mellom land om temaer som vedrører global helse (2).

Norge kom sterkt på banen i 2006 da utenriksminister Jonas Gahr Støre var medskaper av et nytt og unikt initiativ for å koble helse og utenrikspolitikk, sammen med utenriks- ministre fra Frankrike, Brasil, Indonesia, Thailand, Sør-Afrika og Senegal. Denne gruppen er godt kjent som Oslo Ministerial Group og har de siste årene spilt en nøkkelrolle i å sette en ny agenda for utenrikspolitikkens rolle i å fremme global helse (3).

Hvilken betydning har så internasjonale forhandlinger og avtaler i en verden der helsebistanden fra de rikeste til de fattigste landene er firedoblet siden årtusenskiftet (4)? Vi ønsker med denne artikkelen å sette søkelyset på et nytt utenrikspolitisk landskap, der helse som saksområde er blitt mer synlig. Vi trenger mer kunnskap for å kunne vise hvordan utenrikspolitikk påvirker helse, men ønsker her å belyse hvordan utenrikspolitiske initiativer kan virke inn. Vi vil illustrere dette med å se spesielt på arbeidet tilknyttet Oslo Ministerial Group.

\section{Verden i endring}

Da møtet i Paris fant sted på 1800-tallet, var sykdomsutfordringene uløselig knyttet til økt handel på tvers av kontinenter, og en større reisevirksomhet og flere migranter. Utvandringen fra Europa til det amerikanske kontinent var en avgjørende og ny faktor, likeledes åpningen av Suez-kanalen (5).

Da Gro Harlem Brundtland satt i lederstolen i WHO i 1999, var de underliggende bevegelsene de samme, men med en rekke særegne utfordringer: Tiår dominert av den kalde krigens sikkerhetspolitikk og alliansebygging ble avløst av en langt mer uoversiktlig verdensorden. Det var ikke lenger en klar forskjell mellom industrialiserte land og utviklingsland, og saklisten i internasjonal politikk vokste: Sikkerhet var stadig sentralt for alle land, men økonomisk utvikling, handel, miljø og helse hadde fått økende betydning for hvordan landene markerte sine interesser internasjonalt. Utenrikspolitikken var i endring.

Nye sykdomsutfordringer rundt årtusenskiftet satte fart $\mathrm{i}$ aktualiseringen av helse som utenrikspolitisk felt. Sars-utbruddet i 2003 satte en støkk i den vante og uavbrutte flyt av varer og personer. Det startet likevel med hiv/aids- problematikken mer enn et tiår tidligere: Saken havnet ikke bare på helseministerens, men også på utenriksministerens og statslederens kontor. Hvordan sikrer man befolkningen mot slike trusler? For et land som Norge, fantes skremmende scenarioer om eksplosjon i smitte fra nærområder i øst, mens land som Sør-Afrika og Brasil erfarte prisene på hivmedisiner som uakseptable barrierer. Ikke minst gjennom press fra det sivile samfunn ble saken satt på dagsordenen i FN og førte til en bred mobilisering på tvers av grenser. Helseutfordringer kunne ikke løses kun på nasjonalt plan, men krevde også globalt politisk engasjement.

Mulighetene for utstrakt internasjonalt samarbeid tolkes av noen som drømmen om det «gode globale», men hvor reelt er dette? Da mange fryktet en verdensomspennende influensapandemi i 2009, oppsto en ubehagelig påminnelse om utfordringene $i$ avveining av nasjonale versus globale hensyn: De rikeste landene, som Norge, sikret seg raskt dyre kontrakter med vaksineprodusenter for å beskytte sin befolkning. De hadde stående ordre på det meste av den globale produksjonskapasiteten. Fattige land og størsteparten av verdens befolkning hadde liten sjanse for å sikre seg tilsvarende i den akutte fasen med knapphet på vaksiner (6).

\section{Helsediplomatiet}

Influensatrusselen satte fart i den internasjonale forhandlingsprosessen Pandemic Influenzae Preparedness (PIP) i regi av WHO. Prosessen illustrerer godt hvordan helse krysser andre saksområder i internasjonal politikk, og hva helsediplomati består $\mathrm{i}$.

Det var ikke bare fordeling av vaksinene i 2009 som var et problem. Forhandlingene startet i 2007 da Indonesia nektet å dele influensavirus med et WHO-basert nettverk av laboratorier. Nettverket skal sikre mest mulig effektiv deling av informasjon og utvikling av vaksiner. Men, som Indonesia argumenterte, når den farmasøytiske industri så tar patent på vaksiner utviklet av virus fra Indonesia, hva får Indonesia tilbake?

Ettersom PIP-forhandlingene skred frem, ble det stadig tydeligere at det som kunne se ut som en ren helsefaglig sak om bruk av virus med pandemisk influensa-potensial, inkluderte mange temaer der land fra ulike regioner har meget ulike interesser, politiske målsettinger og forutsetninger. Spørs- 


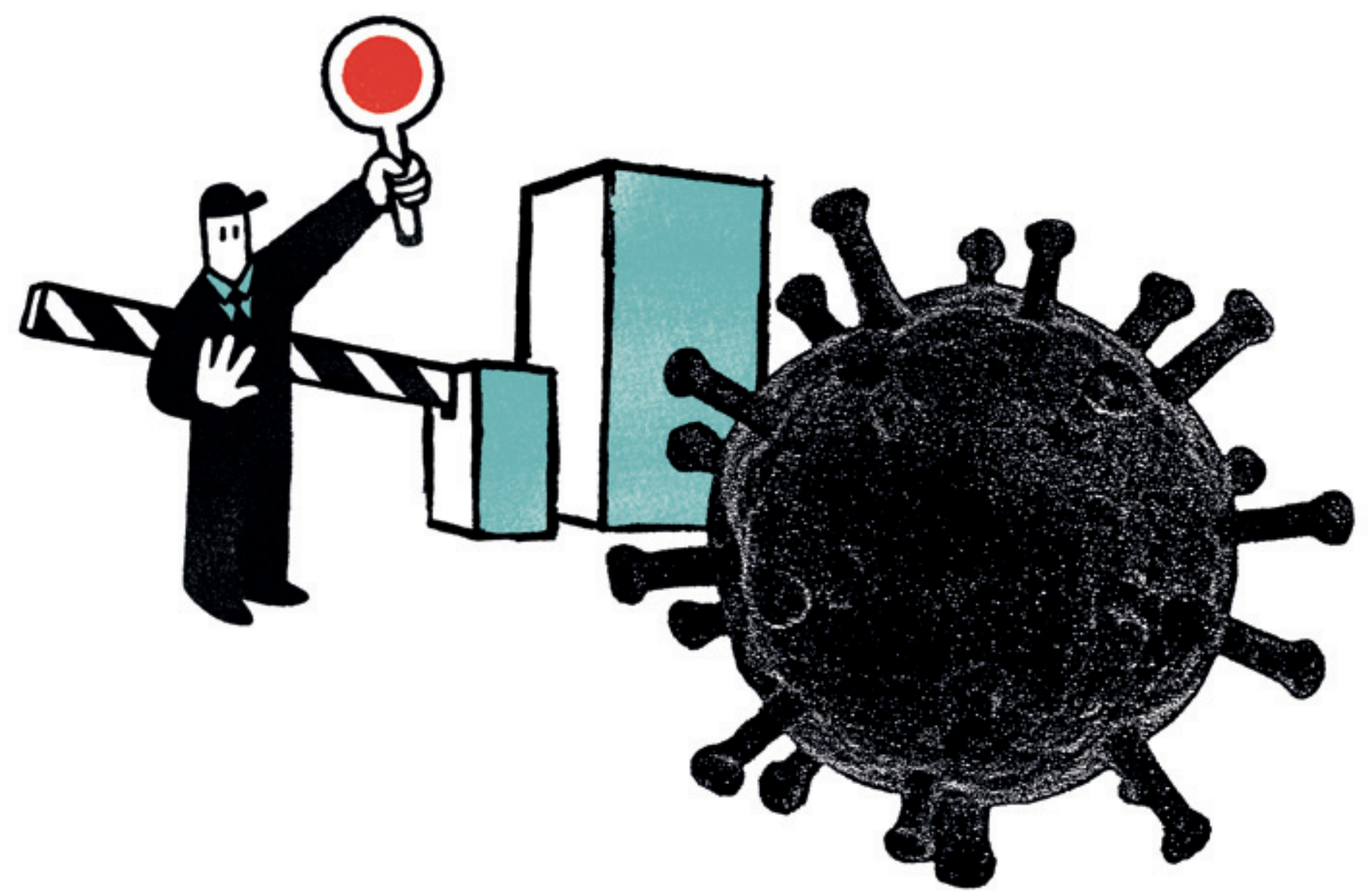

Illustrasjon Supernøtt popsløyd

målet om hvorvidt industri skal ha rett til patentbeskyttelse av vaksiner mot pandemisk influensa strakk seg langt utover forhandlinger innen WHOs rammer og forgrenet seg til forhandlinger for eksempel i Verdens handelsorganisasjon (WTO) og Den internasjonale opphavsrettsorganisasjonen (WIPO).

Det var av avgjørende betydning for en løsning at forhandlingene ble løftet fra «teknokratene», dvs. helseekspertene, til ambassadørnivå, dvs. personer som har tilgang til politikere på sentrale punkter. Selv om sakens kjerne var sykdom og vaksine, kunne ikke landenes utsendte forhandle isolert fra aktører i det sivile samfunn eller næringslivsinteresser, og politiske hensyn ble derfor vesentlig. Det siste året ble forhandlingene ledet av den norske og meksikanske FN-ambassadøren i Genève, der begge hadde stor tillit på tvers av land og regioner. Det var her grunnlaget ble lagt for endelig enighet og en avtale i april 2011.

Helsediplomatiet stiller krav til felles problemløsning. Forhandlingsparter fra utenriksdepartementene er opplært i diplomatiet og har kunnskap om et mangfold av temaer. De teknisk-faglige ekspertene på helse eller de som arbeider med utviklingsbistand er ikke nødvendigvis enige. Ofte er justis- eller handelsdepartement også involvert. Sakene og prosessene går sin gang over flere år, mens diplomatene flytter rundt. Man må derfor ikke bare etterstrebe enighet mellom lands delegasjoner, men også innad i delegasjonene og på tvers av departementer.

\section{The Oslo Ministerial Group}

Utenrikspolitikken har utvidet sitt perspektiv til også å omfatte helse. Betyr det at land nå også er klar til å forholde seg til en ny kompleksitet i internasjonal politikk? Jonas Gahr Støre reflekterte over dette i en tale på Center for Strategic and International Studies i Washington, D.C. i 2009 (7). Tre år tidligere hadde Gahr Støre og hans franske kollega Philippe Douste Blazy ideen til Oslo Ministerial Group, eller The Foreign Policy and Global Health Initiative, som gruppen selv omtaler seg som. De forespurte kolleger de kjente godt fra før, i fem strategisk viktige land, om å bli med.

Oslo-gruppen er uensartet og derfor utradisjonell i internasjonal politikk, der land vanligvis finner hverandre på grunnlag av geografisk tilhørighet eller like interesser (3). Gruppen skrev The Oslo Ministerial Declaration (8), som ble et ambisiøst konsensusdokument med temaer fra migrasjon av helsepersonell til klimakrise. Dokumentet er ikke en handlingsplan for gruppen, men et argument for en vid agenda på global helse med et mål om at økt bevissthet om helse skal påvirke politiske prosesser i andre utenrikspolitiske sektorer, f.eks. FN-prosesser om menneskerettigheter og fredsbygging (8). Ideen er «felles sårbarhet, delt risiko og felles ansvar» $(9$, s. 1$)$.

I 2008 laget gruppen et nettverk mellom Genève-baserte diplomater og skapte et nytt rom for uformelle konsultasjoner. Slike konsultasjoner ble et pusterom i formelle mellomstatlige forhandlingprosesser der sluttdokumenter ofte risikerer å bli utvannet til minste felles multiplum av enighet. Oslogruppen ble et sted der man kunne diskutere ulike politiske målsettinger og perspektiver. Det er en underforstått enighet mellom de sju landene om at gruppen ikke er et forhandlingsforum, men en mulighet til å lære av hverandre, forstå og respektere hverandres ståsteder. En av forfatterne (SHS) deltok under PIP-forhandlingene og erfarte at Oslo-gruppen ble en avgjørende ressurs som var med på å skape et godt forhandlingsklima.

Det er av betydning for gruppen at de sju landene ikke bare representerer fire verdensdeler, men har medlemmer i G8 og G20, og at majoriteten er viktige og sterke utviklingsland. Alle landene i gruppen har spilt betydningsfulle roller. Sør-Afrika, for eksempel, spilte en aktiv rolle i å få i havn tre resolusjoner om helse og utenrikspolitikk i FNs generalforsamling. Sør-Afrika har fra før en sterk posisjon i FN og i den såkalte G-77-gruppen hvor alle 130 utviklingsland deltar. Denne grupperingen ble 
dannet så langt tilbake som i 1964 og opptrer i alle sammenhenger hvor globale spørsmål står på dagsordenen. I 2010 overtok Brasil koordinatorrollen for Oslogruppen. Frem til da hadde Norge hatt et hovedansvar. I likhet med Norge har Brasil en ambisiøs utenrikspolitisk agenda. Brasil utgjør et maktsenter, men begge landene har likevel ambisjoner om å spille en rolle i global politikk.

Helse og utenrikspolitikk, hva så? Det er krevende å måle effekten av Oslo Ministerial Group i en tid der etterprøvbare mål er gullstandarden for globale helseinitiativer. Et innblikk i hvordan helsediplomatiet i Genève arbeider er en av nøklene til å forstå Oslo-gruppens funksjon, en gruppe som verken har allokert penger eller definert milepæler, men snarere vært innstilt på å gripe mulighetene der de oppstår for å forhandle frem løsninger. Spørsmålet på lengre sikt er om gruppen har påvirkningskraft der helse er grenseoverskridende mot andre mer tradisjonelle utenrikspolitiske felt som handel, militære intervensjoner og humanitær bistand.

Enigheten i rammeverket for Pandemic Influenzae Preparedness kan synes spesifikt og teknisk. Men som et eksempel satt i en bredere politisk sammenheng, er avtalen en seier for global sikkerhet, internasjonal solidaritet og for WHO som, av medlemsstatene, gis en klar formell lederrolle som forvalter av internasjonale normer og regler for pandemiberedskap. Forhandlingene er et bevis på at global politikk med et helhetlig humant perspektiv er mulig i en flerfoldig, om enn uoversiktlig, verdensorden.

Initiativet på helse og utenrikspolitikk påvirker også den norske diskusjonen om global helse. Frem til 2006 var fokus i hovedsak på helsebistand til de fattigste landene og nye globale initiativer, som GAVI-alliansen og Det globale fondet for tuberkulose, HIV og malaria. Gahr Støre kom tilbake fra Brundtlands lederteam i WHO med erfaringer som strakk seg utover bistandsperspektivet, bl.a. betydningen av å se forbindelsene mellom alle land når det gjelder helseutfordringer. Utenriksdepartementets beslutning om å sette helse på den utenrikspolitiske agendaen løftet diskusjonen om WHO og dets rolle i styringen av en global helsepolitikk. Diskusjonen favner langt bredere enn bistandsdebatten; om global helse som del av en helhet, inn i en utenrikspolitisk kontekst (3).

Kaster vi igjen et blikk tilbake på den første rekken av International Sanitary Conferences på 1800-tallet, er det interessant å merke seg at forhandlingen var preget av uenighet om årsakene til kolera. I nærmere 40 år varte denne diskusjonen før par- tene kom til enighet (1). Mye har skjedd siden den gang i utviklingen av medisinsk kunnskap og legens verktøy. I vår tid er vi også bevisst på sammenhengen mellom bedre levekår og økt levealder. Denne sammenhengen, omtalt som sosiale helsedeterminanter, reiser spørsmål om hvordan nasjonal og global politikk påvirker helsen. Om man leser det nye utenrikspolitiske terrenget som et område der miljø, matvaretilgang og uro i finansmarkeder henger sammen, kan da vektlegging av helse spore an til uprøvde løsninger?

\section{Kristin Ingstad Sandberg (f. 1972)}

er ph.d. og leder for forskningsprosjektet på helse og utenrikspolitikk ved Senter for utvikling og miljø, i tillegg til postdoktor.doc. på Institutt for helse og samfunn, Universitetet i Oslo. Har faglig bakgrunn innenfor internasjonal politikk og økonomi.

Oppgitte interessekonflikter: Mottatt støtte fra Utenriksdepartementet til forskningsprosjekt på helse og utenrikspolitikk som startet mars 2011.

\section{Steinar Andresen (f. 1951)}

er statsviter, internasjonal politikk, og forskningsprofessor (forsker 1) på Fridtjof Nansens Institutt. Har også vært professor på Institutt for statsvitenskap, Universitetet i Oslo (2002-06). Han har en betydelig internasjonal produksjon av bøker og artikler om internasjonal miljøpolitikk. De senere årene har han også arbeidet med internasjonal helsepolitikk. Ingen oppgitte interessekonflikter.

\section{Sissel Hodne Steen}

er for tiden ministerråd/nestleder ved den norske ambassade i Brasilia.

Ingen oppgitte interessekonflikter.

\section{Sigrun Møgedal (f. 1943)}

er lege og spesialrådgiver ved Kunnskapssenteret. Hun har vært Norges ambassadør for hiv/aids-arbeidet og det globale helseinitiativ, seniorrådgiver i Norad og direktør ved Diakonhjemmets internasjonale senter.

Ingen oppgitte interessekonflikter.

\section{Graziella Van den Bergh ( f. 1956)}

er førsteamanuensis ved Høgskolen i Bergen, med bakgrunn som fysioterapeut, MPhil i Health Promotion og dr. polit. i sosialantropologi. Hun forsker innenfor reproduktiv helse, hiv/aids, funksjonshemning og helsetjenester i Norge, Tanzania og Sudan.

Ingen oppgitte interessekonflikter.

\section{Kristine Husøy Onarheim (f.1987)}

er medisinstudent og forskerlinjestudent ved Universitetet i Bergen. Hun har også studert Global helse ved samme universitet. Ingen oppgitte interessekonflikter.
Litteratur

1. Harvard University library open collections program. Contagion: historical views of diseases and epidemics. International Sanitary Conferences. http./ocp.hul.harvard edu/contagion/ sanitaryconferences.html (19.7. 2011).

2. Kickbusch I. Global health diplomacy: how foreign policy can influence health. BMJ 2011; 342: d3154.

3. Sandberg K, Andresen S. From development aid to foreign policy: global immunization efforts as a turning point for Norwegian engagement in global health. Forum Dev Stud 2010; 37: 301-25.

4. Ravishankar N, Gubbins P, Cooley RJ et al. Financing of global health: tracking development assistance for health from 1990 to 2007. Lancet 2009; 373: $2113-24$

5. Ersoy N, Gungor Y, Akpinar A. International Sanitary Conferences from the Ottoman Perspective (1851-1938). Hygiea Internationalis 2011: 10: $53-79$

6. Brown D. 'US to donate 10 percent of Swine Flu vaccine to WHO. Washington Post, September 18. 2009. /www.washingtonpost.com/wp-dyn/content/ article/2009/09/17/AR2009091704297.html?hpid= moreheadlines (4.8.2011)

7. Støre JG. 2009, Global health: how to make a difference. Tale, CSIS Global Health Policy Center Washington, D.C., 7.4. 2009, www.regjeringen.no/ $\mathrm{nb} /$ dep/ud/aktuelt/taler_artikler/ utenriksministeren/2009/ global health. html?id=554511 (27.6. 2011)

8. Oslo Ministerial Declaration - global health a pressing foreign policy issue of our time. Lancet 2007; 369: 1373-8.

9. Møgedal S, Alveberg BL. Can foreign policy make a difference to health? PLoS Med 2010; 7 e1000274.

Mottatt 23.6. 2011, første revisjon innsendt 11.7. 2011, godkjent 4.8. 2011. Medisinsk redaktør Siri Lunde. 